\title{
Construction and Characterization of a Highly Regulable Expression Vector, pLAC11, and Its Multipurpose Derivatives, pLAC22 and pLAC33
}

\author{
James W. Warren,* Jennifer R. Walker,* John R. Roth, $\dagger$ and Elliot Altman : $^{1}$ \\ *Department of Microbiology and $\ddagger$ Department of Biological and Agricultural Engineering, University of Georgia, \\ Athens, Georgia 30602; and †Department of Biology, University of Utah, Salt Lake City, Utah 84112
}

Received November 15, 1999

\begin{abstract}
A number of different expression vectors have been developed to facilitate the regulated overproduction of proteins in Escherichia coli and related bacteria. Some of the more popular ones include pKK223-3, pKK233-2, pTrc99A, and the pET family of expression vectors. These vectors were designed to be regulable and can be grown under conditions that repress protein production or under conditions that induce protein production. Unfortunately, however, numerous researchers have found that these vectors produce significant amounts of protein even when grown under repressed conditions. We describe here a new expression vector, pLAC11, which was designed to be more regulable and thus more tightly repressible when grown under repressed conditions. The tight regulation of pLAC11 was achieved by utilizing the $\mathrm{O} 3$ auxiliary operator, CAP binding site, promoter, and $\mathrm{O} 1$ operator that occur in the wild-type lac control region. The pLAC11 vector can be used to conduct physiologically relevant studies in which the cloned gene is expressed at levels comparable to that obtainable from the chromosomal copy of the gene in question. In experiments in which a bacterial cell contained both a null allele in the chromosome and a second copy of the wild-type allele on pLAC11, we observed that cells grown under repressed conditions exhibited the null phenotype while cells grown under induced conditions exhibited the wild-type phenotype. Two multipurpose derivatives of pLAC11, pLAC22, and pLAC33 have also been constructed to fulfill different experimental needs. (C) 2000 Academic Press

Key Words: cloning; inducible; plasmid; repressible.
\end{abstract}

Most of the routinely employed expression vectors rely on lac control in order to overproduce a gene of choice (Brosius, 1988; Balbás and Bolivar, 1990). With the wild-type lac promoter/operator, induction ratios of up to $1000 \times$ have been observed between repressed versus induced growth conditions (Beckwith and Zipser, 1970). The lac promoter/operator functions as it does due to the interplay of three main components (the wild-type lac control region is shown in Fig. 1; for general reviews, see Glass, 1982; and Müller-Hill, 1996). First, the wildtype $l a c-10$ region (TATGTT) is very weak. c-AMP-activated CAP protein is able to bind to the CAP site just upstream of the -35 region which stimulates binding of RNA polymerase

\footnotetext{
${ }^{1}$ To whom correspondence should be addressed at Center for Molecular BioEngineering, Department of Biological and Agricultural Engineering, Driftmier Engineering Building, University of Georgia, Athens, GA 30602. Fax: (706) 542-8806. E-mail: EAltman@arches.uga.edu.
}

to the promoter. Repression of the lac promoter is observed when glucose is the main carbon source because very little c-AMP is present and thus low amounts of c-AMP-activated CAP protein are available. When poor carbon sources such as lactose or glycerol are used, c-AMP levels rise, large amounts of c-AMP-activated CAP protein become available, and thus induction of the lac promoter can occur. Second, Lac repressor binds to the lac operator which prevents transcription of the lac operon. Lac repressor can be overcome by allolactose which is a natural by-product of lactose utilization in the cell or by the gratuitous inducer IPTG. ${ }^{2}$ Third, the lac operator can form stable loop structures which prevents the initiation of transcription

\footnotetext{
${ }^{2}$ Abbreviations used: $\Delta$, deletion; E., Escherichia; IPTG, isopropyl $\beta$-D-thiogalactopyranoside; LB, Luria-Bertani; PCR, polymerase chain reaction; ${ }^{\mathrm{R}}$, resistance/resistant; SD, Shine-Dalgarno; Tn, transposon; XGal, 5-bromo-4-chloro3 -indoyl $\beta$-D-galactopyranoside.
} 


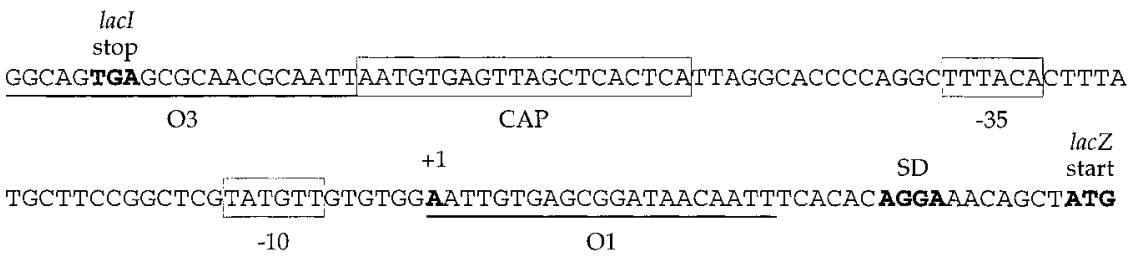

FIG. 1. Control region of the wild-type lac operon. The region from the $\mathrm{O} 3$ auxiliary operator through the translational start of the lac $Z$ gene is shown. DNA binding sites are indicated below the DNA sequence while important RNA sites are shown above the DNA sequence. The Shine-Dalgarno ribosome binding site for lac $Z$ is indicated by SD.

due to the interaction of the Lac repressor with the lac operator $(\mathrm{O} 1)$ and one of two auxiliary operators, $\mathrm{O} 2$ which is located downstream in the coding region of the lac $\mathrm{Z}$ gene or $\mathrm{O} 3$ which is located just upstream of the CAP binding site.

While binding of Lac repressor to the lac operator is the major effector of lac regulation, the other two components are not dispensable. Unfortunately, most of the routinely used lacregulable vectors contain either mutations or deletions which alter the effect of the other two components. The pKK223-3 (Brosius and Holy, 1984), pKK233-2 (Amann and Brosius, 1985), pTrc99A (Amann et al., 1988), and pET family of vectors (Studier et al., 1990) contain only the lac operator (O1) and lack both the CAP binding site and the $\mathrm{O} 3$ auxiliary operator. pKK223-3, pKK233-2, and pTrc99 use a trplac hybrid promoter that contains the trp -35 region and the lacUV5 - 10 region which contains a strong TATAAT site instead of the weak TATGTT site. The pET family of vectors uses the strong T7 promoter. Given this information, perhaps it is not surprising that researchers have found it is not possible to tightly shut off genes that are cloned into these vectors. The promoter/ operator control regions utilized by these vectors are shown in Fig. 2.

We wanted to design a vector which would allow researchers to be able to better regulate

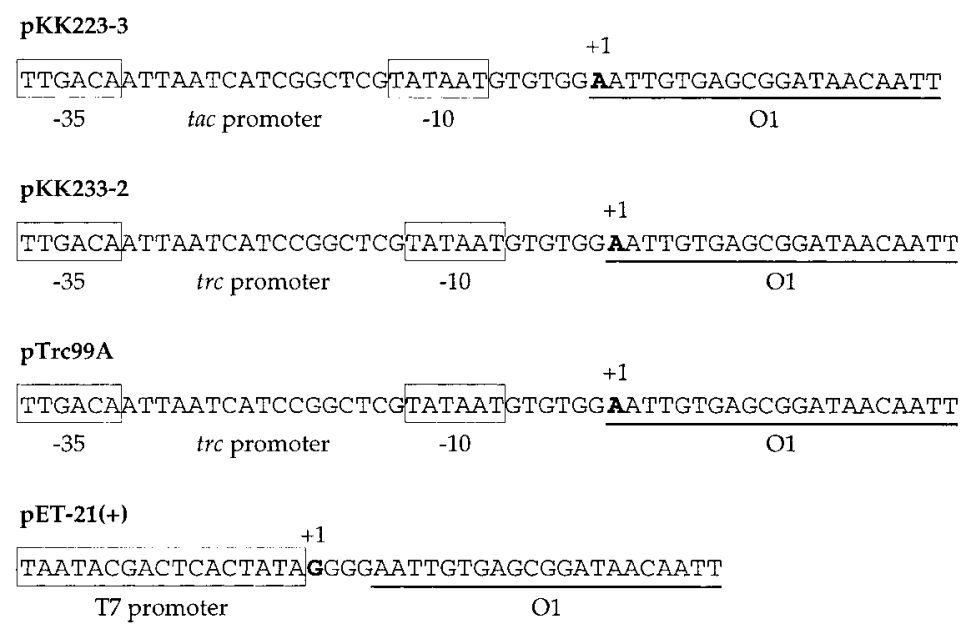

FIG. 2. Control regions of routinely employed expression vectors. The region from the promoter through the lac $\mathrm{O} 1$ operator for the pKK223-3, pKK233-2, pTrc99A, and pET-21(+) vectors is shown. DNA binding sites are indicated below the DNA sequence while important RNA sites are shown above the DNA sequence. The pET-21(+) control region is typical of the control region that is found in other pET expression vectors. Note that the pKK223-3, pKK233-2, pTrc99A, and pET-21(+) expression vectors do not contain a CAP binding site and lack an auxiliary lac operator. 
their cloned genes in order to conduct physiological experiments. The expression vectors described here were designed utilizing the wildtype lac promoter/operator to accomplish this purpose and include all of the lac control region that is contained between the start of the $\mathrm{O} 3$ auxiliary operator through the end of the $\mathrm{O} 1$ operator (see Fig. 1). As with all lac-based vectors, the pLAC11, pLAC22, and pLAC33 expression vectors that we have constructed can be turned on or off by the presence or absence of the gratuitous inducer IPTG.

\section{MATERIALS AND METHODS}

\section{Media}

Minimal M9 and rich LB media used in this study were prepared as described by Miller (1972). The antibiotics ampicillin, kanamycin, streptomycin, and tetracycline were used in rich media at final concentrations of 100, 40, 200, and $20 \mu \mathrm{g} / \mathrm{ml}$, respectively. When used in minimal media, tetracycline was added at a final concentration of $10 \mu \mathrm{g} / \mathrm{ml}$. XGal was added to media at a final concentration of $40 \mu \mathrm{g} / \mathrm{ml}$, glucose was added to media at a final concentration of $0.2 \%$, and unless otherwise noted IPTG was added to media at a final concentration of $1 \mathrm{mM}$.

\section{Bacterial Strains and Plasmids}

The bacterial strains and plasmids that were used in this study are listed in Table 1. To construct ALS225, ALS224 was mated with ALS216 and streptomycin-resistant, blue recombinants were selected on a rich LB plate that contained streptomycin, XGal, and IPTG. To construct ALS226, ALS224 was mated with ALS217 and streptomycin-resistant, kanamycin-resistant recombinants were selected on a rich LB plate that contained streptomycin and kanamycin. To construct ALS515, ALS514 was mated with ALS216 and streptomycin-resistant, blue recombinants were selected on a rich LB plate that contained streptomycin, XGal, and IPTG. To construct ALS527, ALS524 was mated with ALS224 and streptomycin-resistant, tetracycline-resistant recombinants were se- lected on a rich LB plate that contained streptomycin and tetracycline. To construct ALS533, a P1 lysate prepared from ALS213 was used to transduce ALS224 and tetracycline-resistant transductants were selected. To construct ALS535, ALS533 was mated with ALS498 and tetracycline-resistant recombinants were selected on a minimal M9 glucose plate that contained tetracycline, leucine, and thiamine $\left(B_{1}\right)$. To construct ALS611, a P1 lysate prepared from ALS420 was used to transduce ALS410 and tetracycline-resistant white transductants were selected on a rich LB plate that contained tetracycline, XGal, and IPTG. To construct ALS749, a P1 lysate prepared from ALS611 was used to transduce ALS221 and tetracyclineresistant white transductants were selected on a rich LB plate that contained tetracycline, XGal, and IPTG.

\section{Construction of the pLAC11, pLAC22, and pLAC33 Expression Vectors}

To construct pLAC11, primers 1 and 2 (see Table 2) were used to PCR amplify a 953-bp fragment from the plasmid $\mathrm{pBH} 20$ which contains the wild-type lac operon. Primer 2 introduced two different base-pair mutations into the seven-base spacer region between the ShineDalgarno site and the ATG start site of the lacZ which converted it from AACAGCT to AAGATCT, thus placing a $B g l I I$ site between the Shine-Dalgarno and the start codon of the lac Z gene. The resulting fragment was gel isolated, digested with PstI and EcoRI, and then ligated into the 3613-bp fragment from the plasmid pBR322 $\Delta A v a \mathrm{I}$ (described below) which had been digested with the same two restriction enzymes. To construct pBR322 $\Delta A v a \mathrm{I}, \mathrm{pBR} 322$ was digested with $A v a \mathrm{I}$, filled in using Klenow, and then religated.

To construct pLAC22, a 1291-bp NcoI, EcoRI fragment was gel isolated from pLAC21 (described below) and ligated to a 4361-bp NcoI, EcoRI fragment which was gel isolated from pBR322/NcoI (described below). To construct pLAC21, primers 2 and 3 (see Table 2) were used to PCR amplify a 1310-bp fragment from the plasmid pMS421 which contains the 
TABLE 1

Bacterial Strains and Plasmids Used in this Work

\begin{tabular}{|c|c|c|c|}
\hline Laboratory name & Original name & Genotype & Reference or source \\
\hline \multicolumn{4}{|c|}{ Bacterial strains (E. coli) } \\
\hline ALS213 & K5096 & proAB::Tn10 & $\begin{array}{l}\text { Miller and Friedman } \\
\text { (1980) }\end{array}$ \\
\hline ALS216 & SE9100 & $\begin{array}{l}\text { araD139D(lac)U169 thi f1bB5301 deoC7 } \\
\quad \text { ptsF25 rpsE/F'lacI }{ }^{Q 1} Z^{+} Y^{+} A^{+}\end{array}$ & Altman et al. (1990) \\
\hline ALS217 & SE9100.1 & $\begin{array}{l}\text { araD139 } \Delta(\text { lac }) U 169 \text { thi f1bB5301 deoC7 } \\
\text { ptsF25 rpsE/F' } \text { lacI }^{Q I} Z:: T n 5 Y+A+\end{array}$ & S. Emr \\
\hline ALS221 & BL21(DE3) & ompT hsdS(b) $(\mathrm{R}-\mathrm{M}-)$ gal dcm (DE3) & $\begin{array}{l}\text { Studier and Moffatt } \\
\text { (1986) }\end{array}$ \\
\hline ALS224 & MC1061 & $\begin{array}{l}\text { araD139 } \Delta(\text { araABOIC-leu }) 7679 \Delta(\text { lac }) X 74 \\
\quad \text { galU galK rpsL hsr- hsm }+\end{array}$ & $\begin{array}{l}\text { Casadaban and Cohen } \\
\text { (1980) }\end{array}$ \\
\hline ALS225 & & $\mathrm{MC} 1061 / \mathrm{F}^{\prime}$ lacI $^{Q I} Z^{+} Y^{+} A^{+}$ & This work \\
\hline ALS226 & & $\mathrm{MC} 1061 / \mathrm{F}^{\prime}$ lacI $^{Q 1} Z:: \operatorname{Tn} 5 Y^{+} A^{+}$ & This work \\
\hline ALS269 & $\mathrm{CSH} 27$ & $\mathrm{~F}^{-}$trpA33 thi & Miller (1972) \\
\hline ALS410 & CSH1 & $\mathrm{F}^{-}$trp lacZ rpsL thi & Miller (1972) \\
\hline ALS413 & MG1655 & E. coli wild-type $\mathrm{F}^{-} \lambda^{-}$ & Guyer et al. (1980) \\
\hline ALS420 & RS1071 & $\begin{array}{l}\text { leuB6 fhuA2 zah-281::Tn10 glnV44(AS) gal-6 } \\
\text { lambda- trp-31 hisG1(Fs) argG6 rpsL104 } \\
\text { malT1(lambda res) xylA7 mtlA2 metB1 }\end{array}$ & R. Simons \\
\hline ALS498 & JM101 & $\begin{array}{l}\text { supE thi } \Delta(\text { lac-proAB }) / \mathrm{F}^{\prime} \text { traD36 } \text { proA }^{+} B^{+} \\
\quad \text { lacI }^{Q} \Delta(\text { lacZ }) M 15\end{array}$ & Yanisch-Perron (1985) \\
\hline ALS514 & NM554 & MC1061 recA13 & Raleigh et al. (1988) \\
\hline ALS515 & & MC1061 recA13/F' $\mathrm{FacI}^{Q 1} Z^{+} Y^{+} A^{+}$ & This work \\
\hline ALS524 & XL1-Blue & $\begin{array}{l}\text { recAl endA1 gyrA96 thi-1 hsdR17 supE44 } \\
\quad \text { relA1 lac } / \mathrm{F}^{\prime} \text { proAB } \text { lacl }^{Q} \Delta(\text { lacZ)M15 Tn10 }\end{array}$ & Stratagene \\
\hline ALS527 & & 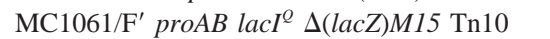 & This work \\
\hline ALS533 & & MC1061 proAB::Tn10 & This work \\
\hline ALS535 & & 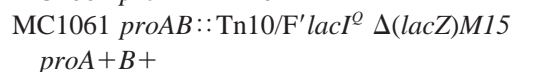 & This work \\
\hline ALS598 & CAG18615 & zjb-3179::Tn10dKan lambda- $r p h-1$ & Singer et al. (1989) \\
\hline ALS611 & & CSH1 zah-281::Tn10 & This work \\
\hline ALS749 & & BL21(DE3) lacZ zah-281::Tn10 & This work \\
\hline \multicolumn{4}{|c|}{ Plasmids } \\
\hline Plasmid name & \multicolumn{2}{|c|}{ Relevant characteristics } & erence or source \\
\hline $\mathrm{pBH} 20$ & \multicolumn{2}{|c|}{$\begin{array}{l}\text { Wild-type lac promoter/operator, } \mathrm{Amp}^{\mathrm{R}}, \mathrm{Tet}^{\mathrm{R}}, \mathrm{ColE} 1 \\
\text { replicon }\end{array}$} & Itakura et al. (1977) \\
\hline pBR322 & \multicolumn{2}{|c|}{$\mathrm{Amp}^{\mathrm{R}}, \mathrm{Tet}^{\mathrm{R}}$, ColE1 replicon } & Bolivar et al. (1977) \\
\hline pET-21(+) & \multicolumn{2}{|c|}{$\mathrm{T} 7$ promoter/lac operator, $l a c I, \mathrm{Amp}^{\mathrm{R}}$, ColE1 replicon } & \\
\hline pGE226 & Wild-type $r e c A$ & $A m p^{R}$ & and Weinstock (1985) \\
\hline pKK223-3 & tac promoter/op & or, Amp ${ }^{R}$, ColE1 replicon & d Holy (1984) \\
\hline pKK233-2 & trc promoter/op & r, Amp ${ }^{\mathrm{R}}$, ColE1 replicon & Brosius (1985) \\
\hline pLysE & $\mathrm{T} 7$ lysozyme, $\mathrm{C}$ & P15A replicon & 91) - - 2 \\
\hline pLysS & T7 lysozyme, $\mathrm{C}$ & P15A replicon & 91) \\
\hline pMS421 & $\begin{array}{l}\text { Wild-type lac } \mathrm{p} \\
\text { SC101 replic }\end{array}$ & oter/operator, lacl $^{Q}$, Strep $^{\mathrm{R}}, \mathrm{Spec}^{\mathrm{R}}$ & (1988) \\
\hline pTer7 & Wild-type lacZ & ng region, $\mathrm{Amp}^{\mathrm{R}}$ & \\
\hline pTrc99A & $\operatorname{trc}$ promoter/op & r, lacI $^{Q}, \mathrm{Amp}^{\mathrm{R}}$, ColE1 replicon & al. $(1988)$ \\
\hline pUC8 & lac promoter/op & or, Amp ${ }^{\mathrm{R}}$, ColE1 replicon & Messing (1982) \\
\hline pXE60 & Wild-type TOL & WO xylE gene, $A^{2} p^{\mathrm{R}}$ & ling \\
\hline
\end{tabular}


TABLE 2

Primers Employed to PCR Amplify DNA Fragments That Were Used in the Construction of the Various Plasmids Described in This Study

\begin{tabular}{|c|c|}
\hline \multicolumn{2}{|r|}{ pLAC11 and pLAC22 } \\
\hline 1 (for) & $\underline{\text { GTT GCC }} \underline{\text { ATT GCT }} \underline{\text { GCA }} \underline{\text { GGC }} \underline{\text { AT }}$ \\
\hline 2 (rev) & 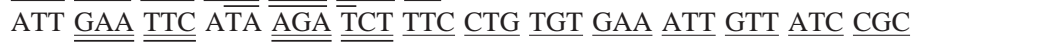 \\
\hline 3 (for) & 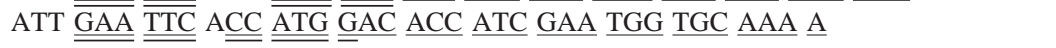 \\
\hline \multicolumn{2}{|r|}{ pBR322/NcoI } \\
\hline 4 (for) & GTT GTT GCC ATT GCT GCA $\underline{G}$ \\
\hline $5(\mathrm{rev})$ & 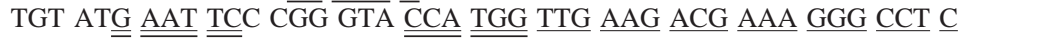 \\
\hline \multicolumn{2}{|r|}{ BglII-lacZ-HindIII } \\
\hline 6 (for) & TAC TAT $\underline{\underline{\text { AGA }}} \underline{\underline{\text { TCT }}} \underline{\text { ATG }} \underline{\text { ACC }} \underline{\text { ATG }} \underline{\text { ATT }} \underline{\text { ACG }} \underline{\underline{\text { GAT TCA }}} \underline{\underline{\text { CTG }}}$ \\
\hline 7 (rev) & TAC ATA $\underline{\overline{\text { AAG }}} \underline{\overline{\text { CTT }}} \overline{\text { GGC }} \underline{\text { CTG }} \underline{\text { CCC }} \underline{\text { GGT TAT TAT TAT TTT }}$ \\
\hline \multicolumn{2}{|r|}{ PstI-lacZ-HindIII } \\
\hline 8 (for) & 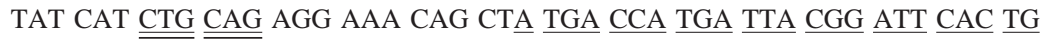 \\
\hline 9 (rev) & TAC ATA $\overline{\overline{\mathrm{CTC}}} \overline{\overline{\mathrm{GAG}}}$ CAG GAA AGC TTG $\overline{\underline{\text { GCC }}} \underline{\underline{\text { TGC }}} \overline{\overline{\text { CCG }}} \underline{\overline{\text { GTT }}} \overline{\overline{\text { ATT }}} \overline{\text { ATT }} \overline{\text { ATT }} \overline{\underline{\text { TT }}}$ \\
\hline \multicolumn{2}{|r|}{ BamHI-lacZ-HindIII (also uses primer \#9) } \\
\hline 10 (for) & 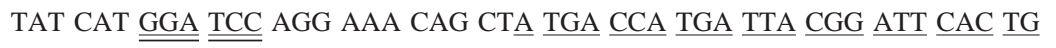 \\
\hline \multicolumn{2}{|r|}{ BglII-recA-HindIII } \\
\hline 11 (for) & TAC TAT $\underline{\underline{\text { AGA }}} \underline{\underline{\text { TCT }}} \underline{\underline{\text { ATG }}} \underline{\underline{\text { GCT }}} \underline{\text { ATC }} \underline{\text { GAC GAA }} \underline{\text { AAC }} \underline{\text { AAA }} \underline{\underline{\text { CAG }}}$ \\
\hline $12($ rev) & ATA TAT $\underline{\underline{\text { AAG }}} \underline{\underline{\text { CTT }}} \underline{\underline{T T A}} \underline{\text { AAA }} \underline{\text { ATC }} \underline{\text { TTC }} \underline{\text { GTT }} \underline{\text { AGT }} \underline{\underline{T C C} \text { TGC }} \underline{\text { TAC }} \underline{\mathrm{G}}$ \\
\hline \multicolumn{2}{|r|}{ HindIII-recA-HindIII } \\
\hline 13 (for) & TAC TAT AAG CTT AGG AAA CAG CTA TGG CTA TCG ACG AAA ACA AAC AG \\
\hline $14(\mathrm{rev})$ & 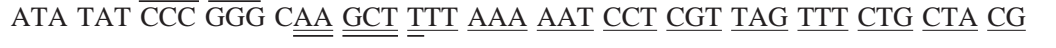 \\
\hline \multicolumn{2}{|r|}{ BamHI-xylE-EcoRI } \\
\hline 15 (for) & TAC TAT $\underline{\underline{\text { AGA }}} \underline{\underline{\text { TCT }}} \underline{\text { ATG }} \underline{\text { AAC }} \underline{\text { AAA GGT }} \underline{\underline{G T A}} \underline{\text { ATG }} \underline{\underline{\text { CGA }}} \underline{\underline{\text { CC }}}$ \\
\hline 16 (rev) & 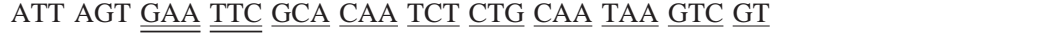 \\
\hline
\end{tabular}

Note. The regions of the primers that are homologous to the DNA target template are indicated with a double underline, while the relevant restriction sites are indicated with a single underline. All primers are listed in the $5^{\prime}$ to $3^{\prime}$ orientation.

wild-type $l a c$ operon as well as the $l a c I^{Q}$ repressor. The resulting fragment was gel isolated, digested with EcoRI, and then ligated into pBR322 which had also been digested with EcoRI. To construct pBR322/NcoI, primers 4 and 5 (see Table 2) were used to PCR amplify a 789-bp fragment from the plasmid pBR322. The resulting fragment was gel isolated, digested with PstI and EcoRI, and then ligated into the 3609-bp fragment from the plasmid pBR322, which had been digested with the same two restriction enzymes. The pBR322/ $N c o$ I vector also contains added KpnI and SmaI sites in addition to the new $N c o$ I site.

To construct pLAC33, a 2778-bp fragment was gel isolated from pLAC12 (described below) which had been digested with $B s a \mathrm{BI}$ and $B s a \mathrm{I}$ and ligated to a 960-bp fragment from 
pUC8 which had been digested with AflIII, filled in with Klenow, and then digested with BsaI. To construct pLAC12, a 1311-bp PstI, BamHI fragment was gel isolated from pLAC11 and ligated to a 3232-bp PstI, BamHI fragment which was gel isolated from pBR322.

\section{Compilation of the DNA Sequences for the} pLAC11, pLAC22, and pLAC33 Expression Vectors

All of the DNA that is contained in the pLAC11, pLAC22, and, pLAC33 vectors has been sequenced. The sequence for the pLAC11 vector which is 4547-bp can be compiled as follows: bp $1-15$ is AGATCTTATGAATTC from primer 2 (Table 2); bp $16-1434$ is bp 4-1422 from pBR322 (Accession No. J01749); bp 1435-1442 is TCGGTCGG, caused by filling in the AvaI site in pBR322 $\Delta A v a \mathrm{I}$; bp 14434375 is bp 1427-4359 from pBR322 (Accession No. J01749); and bp 4376-4547 is bp 1106-1277 from the wild-type Escherichia coli lac operon (Accession No. J01636).

The sequence for the pLAC22 vector which is 5652-bp can be compiled as follows: bp 1-15 is AGATCTTATGAATTC from primer 2 (Table 2); bp 16-4370 is bp 4-4358 from pBR322 (Accession No. J01749); bp 4371-4376 is CCATGG which is the NcoI site from pBR322/ NcoI; and bp 4377-5652 is bp 2-1277 from the wild-type E. coli lac operon (Accession No. J01636), except that bp 4391 of the pLAC22 sequence or bp 16 from the wild-type E. coli lac operon sequence has been changed from a " $C$ " to a " $\mathrm{T}$ " to reflect the presence of the $\operatorname{lacl}^{Q}$ mutation (Calos, 1978).

The sequence for the pLAC33 vector which is 3742-bp can be compiled as follows: bp 1-15 is AGATCTTATGAATTC from primer 2 (Table 2); bp 16-1684 is bp 4-1672 from pBR322 (Accession No. J01749); bp 1685-2638 is bp 786-1739 from pUC8 (Accession No. L09132); bp 2639-3570 is bp 3428-4359 from pBR322 (Accession No. J01749); and bp 3571-3742 is bp 1106-1277 from the wild-type E. coli lac operon (Accession No. J01636). In the maps for these vectors the ori is identified as per Balbás et al. (1986), while the lacPO is indicated start- ing with the $\mathrm{O} 3$ auxiliary operator and ending with the O1 operator as per Müller-Hill (1996).

\section{Construction of the pLAC11-, pLAC22-, pLAC33-, pKK223-3-, pKK233-2-, pTrc99A-, and pET-21(+)-lacZ Plasmids}

To construct pLAC11-lacZ, pLAC22-lacZ, and pLAC33-lacZ, primers 6 and 7 (see Table 2) were used to PCR amplify a 3116-bp fragment from the plasmid pTer7 which contains the wild-type $l a c Z$ gene. The resulting fragment was gel isolated, digested with BglII and HindIII, and then ligated into the pLAC11, pLAC22, or pLAC33 vectors which had been digested with the same two restriction enzymes. To construct pKK223-3-lacZ and pKK233-2lacZ, primers 8 and 9 (see Table 2) were used to PCR amplify a 3138-bp fragment from the plasmid pTer7. The resulting fragment was gel isolated, digested with PstI and HindIII, and then ligated into the pKK223-3 or pKK233-2 vectors which had been digested with the same two restriction enzymes. To construct pTrc99AlacZ and pET-21(+)-lacZ, primers 9 and 10 (see Table 2) were used to PCR amplify a 3138-bp fragment from the plasmid pTer7. The resulting fragment was gel isolated, digested with BamHI and HindIII, and then ligated into the pTrc99A or pET-21(+) vectors which had been digested with the same two restriction enzymes.

\section{Construction of the pLAC11-recA and -xylE Plasmids}

To construct pLAC11-recA, primers 11 and 12 (see Table 2) were used to PCR amplify a 1086-bp fragment from the plasmid pGE226 which contains the wild-type $r e c A$ gene. The resulting fragment was gel isolated, digested with $B g l I I$ and HindIII, and then ligated into the pLAC11 vector which had been digested with the same two restriction enzymes. To construct pKK223-3-recA and pKK233-2-recA, primers 13 and 14 (see Table 2) were used to PCR amplify a 1104-bp fragment from the plasmid pGE226. The resulting fragment was gel isolated, digested with HindIII, and then ligated into either the pKK223-3 or pKK233-2 vector 
TABLE 3

$\beta$-Galactosidase levels Obtained in Different Expression Vectors Grown under Either Repressed or Induced Conditions

\begin{tabular}{|c|c|c|c|c|c|}
\hline \multirow{2}{*}{$\begin{array}{l}\text { Host } \\
\text { strain }\end{array}$} & \multirow[b]{2}{*}{ Vector } & \multirow{2}{*}{$\begin{array}{l}\text { Source } \\
\text { of LacI }\end{array}$} & \multicolumn{2}{|c|}{ No. of Miller units observed } & \multirow{2}{*}{$\begin{array}{c}\text { Fold } \\
\text { induction }\end{array}$} \\
\hline & & & Repressed conditions & Induced conditions & \\
\hline ALS224 & None & None & 3 & 6 & - \\
\hline ALS226 & None & $\mathrm{F}^{\prime}$ & 4 & 7 & - \\
\hline ALS226 & pLAC11 & $\mathrm{F}^{\prime}$ & 19 & 11,209 & $590 \times$ \\
\hline ALS224 & pLAC22 & Plasmid & 152 & 13,315 & $88 \times$ \\
\hline ALS226 & pLAC33 & $\mathrm{F}^{\prime}$ & 322 & 23,443 & $73 \times$ \\
\hline ALS226 & pKK223-3 & $\mathrm{F}^{\prime}$ & 92 & 11,037 & $120 \times$ \\
\hline ALS226 & pKK233-2 & $\mathrm{F}^{\prime}$ & 85 & 10,371 & $122 \times$ \\
\hline ALS224 & pTrc99A & Plasmid & 261 & 21,381 & $82 \times$ \\
\hline ALS749 & None & None & 3 & 4 & - \\
\hline ALS749 & pET-21(+) & Plasmid & 2929 & 16,803 & $6 \times$ \\
\hline ALS749 & pET-21(+)/pLysE & Plasmid & 4085 & 19,558 & $5 \times$ \\
\hline ALS749 & pET-21(+)/pLysS & Plasmid & 1598 & 20,268 & $13 \times$ \\
\hline
\end{tabular}

Note. The average values obtained for the four clones that were tested from each vector in two different experiments are listed. Standard deviation is not shown but was less than $5 \%$ in each case. Induction ratios are expressed as the ratios of enzymatic activity observed under fully induced conditions versus fully repressed conditions. Because pLysE yielded unexpected results, we restriction mapped both of the pLysE and pLysS plasmids to make sure that they were correct.

which had been digested with HindIII and dephosphorylated with alkaline phosphatase. To construct pLAC11-xylE, primers 15 and 16 (see Table 2) were used to PCR amplify a 980-bp fragment from the plasmid pXE60 which contains the wild-type Pseudomonas putida xylE gene isolated from the TOL pWWO plasmid. The resulting fragment was gel isolated, digested with $B g l \mathrm{II}$ and $E c o$ RI, and then ligated into the pLAC11 vector which had been digested with the same two restriction enzymes.

\section{$\beta$-Galactosidase and Catechol 2,3- \\ Dioxygenase Assays}

$\beta$-Galactosidase assays were performed as described by Miller (1972), while catechol 2,3dioxygenase assays were performed as described by Zukowski et al. (1983).

\section{P1 Transduction Assay}

Overnights were prepared from each of the strains to be tested using either rich medium to which glucose was added at a final concentration of $0.2 \%$ (repressed conditions) or rich medium to which IPTG was added at a final concentration of $1 \mathrm{mM}$ (induced conditions). The overnights were diluted 1 to 10 into the same medium which contained calcium chloride added to a final concentration of $10 \mathrm{mM}$ and aerated for $2 \mathrm{~h}$ to make them competent for transduction with P1 phage. A 0.1-ml volume of cells at an $\mathrm{OD}_{550}$ of 1.0 was transduced with either $0.1 \mathrm{ml}$ of P1 lysate which had been adjusted to yield a maximal number of transductants or $0.1 \mathrm{ml}$ of a $10^{-2}$ dilution of the lysate. After a $25-\mathrm{min}$ incubation at $37^{\circ} \mathrm{C}, 0.2$ $\mathrm{ml}$ of $0.1 \mathrm{M}$ sodium citrate was added to the cell/phage mixtures and $0.2 \mathrm{ml}$ of the final mixtures was plated onto rich kanamycin plates and incubated overnight at $37^{\circ} \mathrm{C}$. The total number of kanamycin-resistant colonies was then counted. As reported in Table 4, ALS225 recA ${ }^{+}$data points were taken from the transductions which used the $10^{-2}$ diluted phage, while ALS515 recA ${ }^{-}$data points were taken from the transductions which used the concentrated phage. The data points for ALS515 recA $\mathrm{r}^{-}$strains containing a recA ${ }^{+}$ plasmid were taken from transductions which used the concentrated phage when cells were grown under repressed conditions and trans- 
TABLE 4

The Phenotype of a recA Null Mutant Strain Can Be Preserved with a pLAC11-recA (Wild-Type) Construct under Repressed Conditions

\begin{tabular}{|c|c|c|}
\hline & Repressed conditions & Induced conditions \\
\hline Strain & $\begin{array}{c}\text { Number of } \operatorname{Kan}^{\mathrm{R}} \\
\text { transductants }\end{array}$ & $\begin{array}{c}\text { Number of } \operatorname{Kan}^{\mathrm{R}} \\
\text { transductants }\end{array}$ \\
\hline $\operatorname{ALS} 225\left(\mathrm{rec}^{+}\right)$ & 178,000 & 182,000 \\
\hline $\operatorname{ALS515}\left(\mathrm{rec}^{-}\right)$ & 5 & 4 \\
\hline ALS515 (recA $A^{-}$pLAC11-recA) & 4 & 174,000 \\
\hline ALS515 (recA $A^{-}$pKK223-3-recA) & 146 & 179,000 \\
\hline ALS515 (recA- pKK233-2-recA) & 143 & 158,000 \\
\hline
\end{tabular}

Note. The data presented are the numbers of kanamycin-resistant $\left(\operatorname{Kan}^{\mathrm{R}}\right)$ transductants that were obtained from the different isogenic strains when they were transduced with a P1 lysate prepared from strain ALS598 which harbored a Tn10dKan transposon insertion. Cells were grown in rich medium under either repressed or induced conditions, transduced with equal amounts of the P1 lysate, plated onto rich kanamycin plates, and incubated overnight at $37^{\circ} \mathrm{C}$ as described under Materials and Methods. The total number of kanamycin-resistant colonies was then counted.

ductions which used the $10^{-2}$ diluted phage when cells were grown under induced conditions.

\section{Chemicals and Reagents}

When amplified DNA was used to construct the plasmids that were generated in this study, the PCR was carried out using native $P f u$ polymerase from Stratagene. XGal and IPTG were purchased from Diagnostic Chemicals Limited.

\section{RESULTS}

\section{Construction and Features of pLAC11, pLAC22, and pLAC33}

The construction of pLAC11, pLAC22, and pLAC33 is described under Materials and Methods and plasmid maps which indicate the unique restriction sites, drug resistances, origins of replication, and other relevant regions that are contained in these vectors are shown in Fig. 3. Sequences of these three vectors can be compiled as described under Materials and Methods. pLAC11 utilizes the ColE1 origin of replication from pBR322 and Lac repressor is provided in trans from either an episome or another compatible plasmid. pLAC22 is very similar to pLAC11; however, it also contains
lacI $^{Q}$ and thus a source of Lac repressor does not have to be provided in trans. pLAC33 is a derivative of pLAC11 which utilizes the mutated ColE1 origin of replication from pUC8 (Lin-Chao et al., 1992) and thus pLAC33's copy number is significantly higher than pLAC11 and is comparable to that of other pUC vectors. Because the cloning regions of these three vectors are identical, cloned genes can be easily shuffled between these three vectors depending on the expression demands of the experiment in question.

To clone into pLAC11, pLAC22, or pLAC33, PCR amplification is performed with primers that are designed to introduce unique restriction sites just upstream and downstream of the gene of interest (see Fig. 4). Usually a $B g l \mathrm{II}$ site is introduced immediately in front of the ATG start codon and an EcoRI site is introduced immediately following the stop codon. After amplification the dsDNA is restricted with $B g l \mathrm{II}$ and EcoRI and cloned into the vector which has also been restricted with the same two enzymes. If the gene of interest contains a $B g l I I$ site, then BamHI or BclI can be used instead since they generate overhangs which are compatible with $B g l I I$. If the gene of interest contains an EcoRI site, then a site downstream of EcoRI in the vector (such as HindIII) can be 

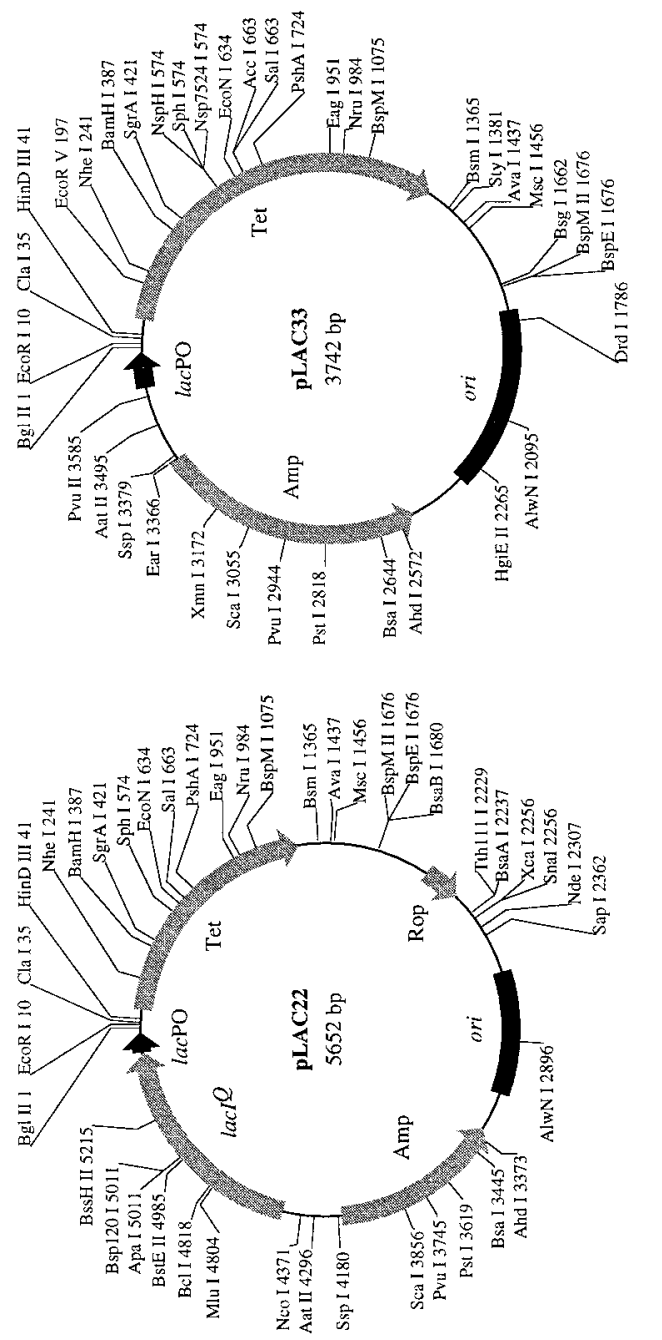

षै.

o $\dot{\hat{0}}$

苞

总空 하일 过 ठํㅏㅇ मेत

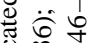
瓷吉 品 言売 정워

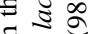
氖 जิ 言娄 范 宅

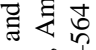
产 $\frac{\hat{0}}{m}$ ฮี ह 吾点 ปั 정 च $\vec{\imath}$ in mे 已ิ

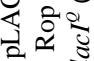

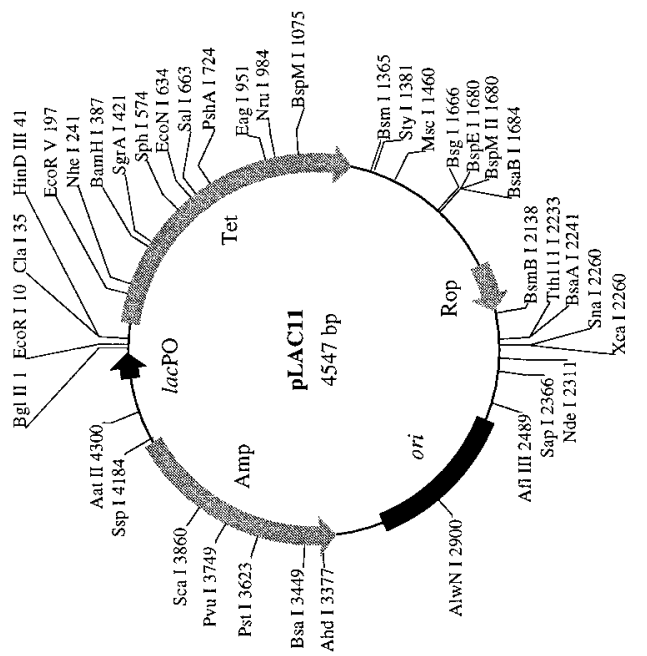

栗 กิ ४⿻ 드 चे 完岕 है

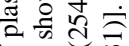
पू

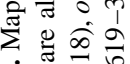
ن.

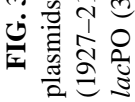




$$
\underset{\text { Bgl II }}{\text { AGATCT ATG } \cdots \cdot \text { Gene X } \cdots \cdot \text { TAAGAATTC }}
$$

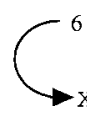

6 extra bases are included so that Bgl II will digest efficiently

$$
\mathrm{Bgl} \mathrm{II}
$$

XXXXXX AGATCT ATGXXXXXXXXXXXXXXXXX Primer \#1

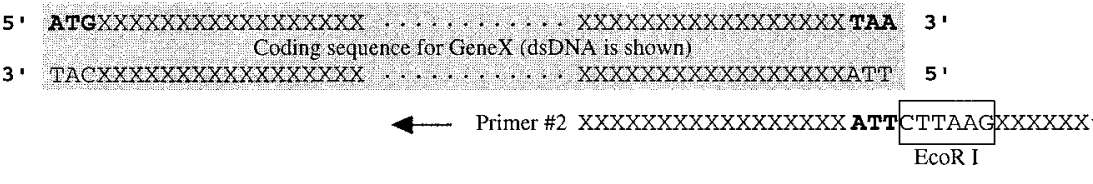

6 extra bases are included so that EcoR I will digest efficiently

The end result is a gene which is regulated by the wild-type lac promoter/operator

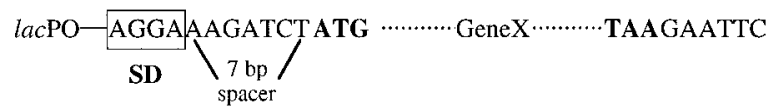

FIG. 4. Cloning into pLAC11, pLAC22, or pLAC33. The coding region of interest can be PCR amplified, cloned into pLAC11, pLAC22, or pLAC33, and placed under lac control.

substituted. As shown in Fig. 4, we place an additional six extra bases at both ends of the oligonucleotide in order to ensure that complete digestion occurs.

\section{Comparison of pLAC11, pLAC22, and pLAC33 to Other Expression Vectors}

In order to demonstrate how regulable the pLAC11, pLAC22, and pLAC33 expression vectors were, the wild-type lacZ gene was cloned into pLAC11, pLAC22, pLAC33, pKK223-3, pKK233-2, pTrc99A, and pET-21(+). Constructs which required an extraneous source of LacI for their repression were transformed into strain ALS226, while constructs which contained a source of LacI on the vector were transformed into strain ALS224. pET-21(+) constructs were transformed into strain ALS749 because they require T7 RNA polymerase for their expression. Four independent lac $Z$ clones were chosen from each vector. The plasmids pLysE and pLysS which make T7 lysozyme and thus lower the amount of available $\mathrm{T} 7$ polymerase were also transformed into each of the four pET-21(+) clones. Rich ampicillin overnights were diluted 1 to 200 in either rich ampicillin glucose medium (repressed conditions) or rich ampicillin IPTG medium (induced conditions) and grown until they reached midlog $\left(\mathrm{OD}_{550}=0.5\right)$. Cell extracts were prepared and $\beta$-galactosidase assays were performed as per Miller (1972). Table 3 shows the results of these studies and also lists the induction ratio that was determined for each of the expression vectors. As the data clearly indicate, pLAC11 is the most regulable of these expression vectors and its induction ratio is close to that which can be achieved with the wild-type lac operon. The vector which yielded the lowest level of expression under repressed conditions was pLAC11, while the vector which yielded the highest level of expression under induced conditions was pLAC33.

\section{Demonstrating That pLAC11 Constructs Can Be Tightly Regulated}

To further demonstrate the utility of pLAC11 for physiological experiments, the rec A gene was cloned into the pLAC11, pKK223-3, and pKK233-2 vectors and transformed into cells which contained a null recA allele in the chromosome. The pKK223-3 and pKK233-2 vectors were chosen as controls because aside from pLAC11, they were the most tightly regulable of all the vectors that were examined in the experiments with lacZ shown in Table 2. As the data in Table 4 clearly show, recombination cannot occur in a host strain which contains a nonfunctional RecA protein and thus P1 lysates which provide a Tn10dKan transposon cannot 


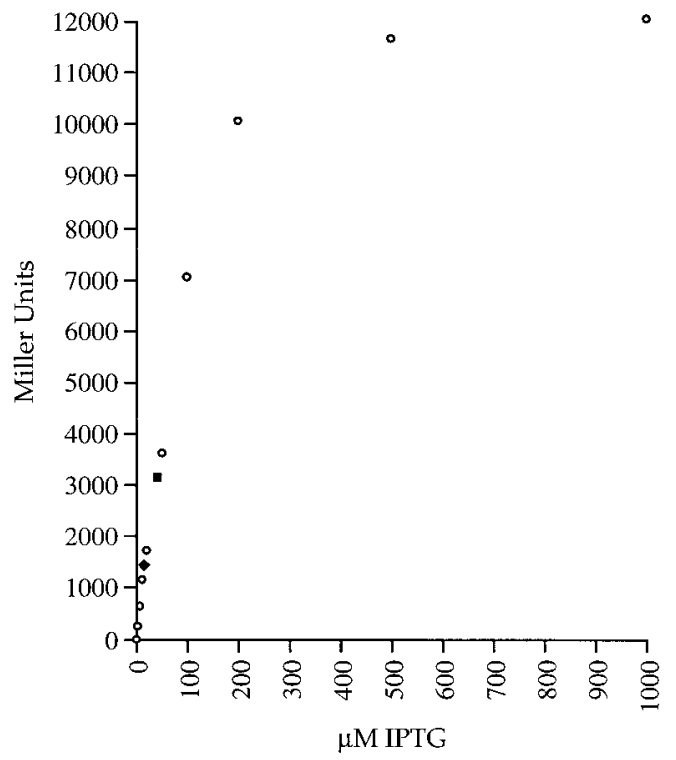

FIG. 5. Response of the pLAC11-lacZ construct to varying amounts of IPTG. ALS226 cells containing pLAC11lac $Z$ were grown to midlog in rich medium that contained varying amounts of IPTG and then $\beta$-galactosidase activity was assayed. These data points are indicated by open circles. Also indicated in the graph are the average $\beta$-galactosidase activities obtained for strains with a single chromosomal copy of the wild-type lac $Z$ gene that were grown under different conditions. A filled square indicates the $\beta$-galactosidase activity that was obtained when MG1655 or $\mathrm{CSH} 27$ cells were grown in rich medium induced with 1 mM IPTG, while a filled diamond indicates the $\beta$-galactosidase activity that was obtained when MG1655 or CSH27 cells were grown in M9 minimal lactose medium.

be used to transduce the strain to kanamycin resistance at a high frequency. A $r e c A^{-}$strain which also contains the pLAC11-recA construct can be transduced to kanamycin resistance at a high frequency when grown under induced conditions but cannot be transduced to kanamycin resistance when grown under repressed conditions. This is not the case for the pKK223-3-recA and pKK233-2-recA constructs as a significant number of transductants above background can be obtained under repressed conditions.

pLAC11 was designed to provide researchers with an expression vector that could be utilized to conduct physiological experiments in which a cloned gene is studied under completely repressed conditions where it is off or partially induced conditions where it is expressed at physiologically relevant levels. Figure 5 demonstrates how a pLAC11-lacZ construct can be utilized to mimic chromosomally expressed lacZ that occurs under various physiological conditions by varying the amount of IPTG inducer added.

\section{Testing Various Sources of LacI for Trans Repression of pLAC11}

Because pLAC11 was designed to be used with an extraneous source of Lac repressor, different episomal or plasmid sources of LacI which are routinely employed by researchers were tested. Since one of the LacI sources also contained the lac $Z$ gene, a reporter construct other than pLAC11-lac $Z$ was required and thus a pLAC11-xylE construct was engineered. Table 5 shows the results of this study. All of the LacI sources that were tested proved to be adequate to repress expression from pLAC11; however, some were better than others. The basal level of expression that was observed with $\mathrm{F}^{\prime} \mathrm{s}$ which provided $l a c I^{Q 1}$ or with the plasmid pMS421 which provided $l a c I^{Q}$ at approximately six copies per cell was lower than the basal level of expression that was observed with $\mathrm{F}^{\prime} \mathrm{s}$ which provided $l a c I^{Q}$ all three times that the assay was performed. Unfortunately, however, the $x y l E$ gene could not be induced as high when $l a c I^{Q l}$ on a $\mathrm{F}^{\prime}$ or $l a c I^{Q}$ on a plasmid was used as the source of Lac repressor.

\section{DISCUSSION}

Most of the routinely employed expression vectors rely on elements of the lac control region for their regulation. While these vectors allow for overexpression of the gene product of interest, they are leaky due to changes that have been introduced into the lac control region and gene expression cannot be completely shut off under repressed conditions. Numerous researchers have noticed this problem with the more popular expression vectors pKK223-3 (Posfai et al., 1986; Scrutton et al., 1987), pKK233-2 (Beremand et al., 1987; Ooki et al., 1994), and pTrc99A (Ranie et al., 1993; Ghosh and Singh, 1997), as well as the pET series (Eren and 
TABLE 5

Catechol 2,3-Dioxygenase Levels Obtained for a pLAC11-xylE Construct When Lac Repressor Is Provided by Various Sources

\begin{tabular}{|c|c|c|c|c|}
\hline \multirow[b]{2}{*}{$\begin{array}{l}\text { Host } \\
\text { strain }\end{array}$} & \multirow[b]{2}{*}{$\begin{array}{c}\text { Plasmid } \\
\text { present }\end{array}$} & \multirow[b]{2}{*}{ Source of LacI } & \multicolumn{2}{|c|}{$\begin{array}{c}\text { Catechol 2,3-dioxygenase activity } \\
\text { in milliunits/mg }\end{array}$} \\
\hline & & & $\begin{array}{l}\text { Repressed conditions } \\
\quad \text { (rich glucose) }\end{array}$ & $\begin{array}{l}\text { Induced conditions } \\
\text { (rich IPTG) }\end{array}$ \\
\hline ALS224 & No & None & 0.2 & 0.2 \\
\hline ALS224 & Yes & None & 32.7 & 432.8 \\
\hline ALS535 & Yes & $\mathrm{F}^{\prime}$ lacI $^{Q} \Delta($ lacZ $) M 15$ proA $+B+\operatorname{Tn} 10$ & 0.3 & 204.4 \\
\hline ALS527 & Yes & $\mathrm{F}^{\prime}$ lacI $^{Q} \Delta($ lacZ)M15 proA $+B+$ & 0.3 & 243.3 \\
\hline ALS227 & Yes & pMS421 lac $I^{Q}$ & 0.2 & 90.9 \\
\hline ALS225 & Yes & $\mathrm{F}^{\prime}$ lacI $^{Q 1} Z^{+} Y^{+} A^{+}$ & 0.2 & 107.4 \\
\hline ALS226 & Yes & $\mathrm{F}^{\prime}$ lac ${ }^{Q 1} Z:: \operatorname{Tn} 5 Y^{+} A^{+}$ & 0.2 & 85.1 \\
\hline
\end{tabular}

Note. The pLAC11-xylE construct was transformed into each of the MC1061 derivative strains listed. ALS224, the parental MC1061 strain, without the pLAC11-xylE construct served as a control. Rich overnights were diluted 1 to 200 in either rich glucose or rich IPTG medium and grown until they reached midlog $\left(\mathrm{OD}_{550}=0.5\right)$. Cell extracts were then prepared and catechol 2,3-dioxygenase assays were performed as described by Zukowski et al. (1983). The average values obtained in three different experiments are listed. Standard deviation is not shown but was less than $10 \%$ in each case. It should be noted that some repression is achieved in ALS224 pLAC11-xylE under repressed conditions, because the addition of glucose prevents the accumulation of high levels of c-AMP.

Swenson, 1989; Godson, 1991). We describe here a new vector, pLAC11, which relies on the wild-type lac control region from the auxiliary lac $\mathrm{O} 3$ operator through the lac $\mathrm{O} 1$ operator and thus can be more tightly regulated than the other available expression vectors. In direct comparison studies with pKK223-3, pKK233-2, pTrc99A, and pET-21(+), we found that the lowest level of expression under repressed conditions was achievable with the pLAC11 expression vector. Under fully induced conditions, pLAC11 expressed LacZ protein at levels which were comparable to what could be achieved with the other expression vectors.

Induction ratios of $1000 \times$ have been observed with the wild-type lac operon. Of all the expression vectors that were tested, only pLAC11 yielded induction ratios which were comparable to what has been observed with the wild-type lac operon. It should be noted that the regulation achievable by pLAC11 is actually better than the data indicated in Table 3. Because lac $Z$ was used in this test, the auxiliary lac $\mathrm{O} 2$ operator which resides in the coding region of the lac $Z$ gene was provided to the pKK223-3, pKK233-2, pTrc99A, and
pET-21(+) vectors which do not normally contain either the $\mathrm{O} 2$ or $\mathrm{O} 3$ auxiliary operators. Thus the repressed states that were observed in the study in Table 3 are lower than what is normally obtainable with the pKK223-3, pKK233-2, pTrc99A, and pET-21(+) vectors. The studies with RecA in Table 4 demonstrate this as RecA protein expression could only be completely shut off under repressed conditions using pLAC11. Significant expression of the RecA protein occurred in the pKK223-3 and pKK233-2 vectors under repressed conditions.

To meet the expression needs required under different experimental circumstances, we also designed two additional expression vectors which are derivatives of pLAC11. pLAC22 provides lacI $^{Q}$ on the vector and thus unlike pLAC11 does not require an extraneous source of LacI for its repression. pLAC33 contains the mutated ColE1 replicon from pUC8 and thus allows proteins to be expressed at much higher levels due to the increase in the copy number of the vector. Of all the expression vectors that we evaluated in direct comparison studies, the highest level of protein expression under fully induced conditions was achieved using the 
pLAC33 vector. Because the cloning regions are identical in pLAC11, pLAC22, and pLAC33, genes that are cloned into one of these vectors can be subcloned into one of the other two vectors depending on experimental circumstances. For physiological studies, pLAC11 is the best suited of the three vectors. If, however, the bacterial strain of choice cannot be modified to introduce elevated levels of Lac repressor protein which can be achieved by $\mathrm{F}^{\prime} \mathrm{s}$ or compatible plasmids that provide $l a c I^{Q}$ or $l a c I^{Q I}$, the pLAC22 vector can be utilized. If maximal overexpression of a gene product is the goal, then the pLAC33 vector should be utilized.

Numerous experiments call for expression of a cloned gene product at physiological levels, i.e., at expression levels that are equivalent to the expression levels observed for the chromosomal copy of the gene. While this is not easily achievable with any of the commonly utilized expression vectors, these kinds of experiments can be done with the pLAC11 expression vector. By varying the IPTG concentrations, expression from the pLAC11 vector can be adjusted to match the expression levels that occur under different physiological conditions for the chromosomal copy of the gene.

Because the use of Lac repressor is an essential component of any expression vector that utilizes the lac operon for its regulation, we also investigated the ability of different sources of LacI to repress the pLAC11 vector. Researchers have historically utilized either $\operatorname{lacl}^{Q}$ constructs which make 10-fold more Lac repressor than wild-type $l a c I$ or $l a c I^{Q 1}$ constructs which make 100-fold more Lac repressor than wild-type lacI (Müller-Hill, 1975). We found that the greatest level of repression of pLAC11 constructs could be achieved using $\mathrm{F}^{\prime} \mathrm{s}$ which provided approximately one copy of the $l a c I^{Q 1}$ gene or a multicopy compatible plasmid which provided approximately six copies of the lacI ${ }^{Q}$ gene. However, the induction that was achievable using these LacI sources was significantly lower than the induction that could be achieved when $\mathrm{F}^{\prime} \mathrm{s}$ which provided approximately one copy of the $l a c I^{Q}$ gene were used to repress the pLAC11 construct. Thus if physiological studies are the goal of an investigation, then $\mathrm{F}^{\prime} \mathrm{s}$ which provide approximately one copy of the $\operatorname{lacI^{QI}}$ gene or a multicopy compatible plasmid which provides approximately six copies of the $\operatorname{lacI}^{Q}$ gene should be used to regulate the pLAC11 vector. However, if maximal expression is desired, then $\mathrm{F}^{\prime} \mathrm{s}$ which provide approximately one copy of the $\operatorname{lacl}^{Q}$ gene should be utilized. Alternatively, if a bacterial strain can tolerate prolonged overexpression of an expressed gene and overexpression of a gene product is the desired goal, then maximal expression under induced conditions is obtained when a bacteria strain lacks any source of Lac repressor.

\section{ACKNOWLEDGMENT}

This work was supported by a Biotechnology Award from the Office of the Vice President for Research, University of Georgia.

\section{REFERENCES}

Altman, E., Bankaitis, V. A., and Emr., S. D. (1990). Characterization of a region in mature LamB protein that interacts with a component of the export machinery of Escherichia coli. J. Biol. Chem. 265, 18148-18153.

Amann, E., and Brosius, J. (1985). ATG vectors for regulated high-level expression of cloned genes in Escherichia coli. Gene 40, 183-190.

Amann, E., Ochs, B., and Abel, K-J. (1988). Tightly regulated tac vectors useful for the expression of unfused and fused proteins in Escherichia coli. Gene 69, 301-315.

Balbás, P., and Bolivar, F. (1990). Design and construction of expression plasmid vectors in Escherichia coli. In "Methods in Enzymology" (D. V. Goeddel, Ed.), Vol. 185, pp. 14-37. Academic Press, San Diego.

Balbás, P., Soberón, X., Merino, E., Zurita, M., Hilda, M., Valle, F., Flores, N., and Bolivar, F. (1986). Plasmid vector pBR322 and its special-purpose derivatives-A review. Gene 50, 3-40.

Beckwith, J. R., and Zipser, D. (Eds.) (1970). "The Lactose Operon." Cold Spring Harbor Laboratory Press, Cold Spring Harbor, NY.

Beremand, P. D., Hannapel, D. J., Guerra, D. J., Kuhn, D. N., and Ohlrogge, J. B. (1987). Synthesis, cloning, and expression in Escherichia coli of a spinach acyl carrier protein-I gene. Arch. Biochem. Biophys. 256, 90-100.

Bolivar, F., Rodriguez, R. L., Greene, P. J., Betlach, M. C., Heyneker, H. L., Boyer, H. W., Crosa, J. H., and Falkow, S. (1977). Construction and characterization of new cloning vehicles II. A multipurpose cloning system. Gene 2, 95-113.

Brosius, J. (1988). Expression vectors employing lambda-, trp-, lac-, and lpp-derived promoters. Biotechnology 10, 205-225.

Brosius, J., and Holy, A. (1984). Regulation of ribosomal 
RNA promoters with a synthetic lac operator. Proc. Natl. Acad. Sci. USA 81, 6929-6933.

Calos, M. P. (1978). DNA sequence for a low-level promoter of the lac repressor gene and an 'up' promoter mutation. Nature 274, 762-765.

Casadaban, M., and Cohen, S. N. (1980). Analysis of gene control signals by DNA fusion and cloning in Escherichia coli. J. Mol. Biol. 138, 179-207.

Eren, M., and Swenson, R. P. (1989). Chemical synthesis and expression of a synthetic gene for the flavodoxin from Clostridium MP. J. Biol. Chem. 264, 14874-14879.

Ghosh, S., and Singh, M. (1997). cDNA cloning, expression, and rapid purification of a Kunitz-type winged bean chymotrypsin inhibitor. Protein Expr. Purif. 10, 100106.

Glass, R. E. (1982). "Gene Function: E. coli and Its Heritable Elements." Univ. California Press, Berkeley and Los Angeles.

Godson, G. N. (1991). An over-expression plasmid for Escherichia coli primase. Gene 100, 59-64.

Graña, D., Gardella, T., and Susskind, M. M. (1988). The effects of mutations in the ant promoter of Phage P22 depend on context. Genetics 120, 319-327.

Guyer, M. S., Reed, R. R., Steitz, J. A., and Low, K. B. (1980). Identification of a sex-factor-affinity site in $E$. coli as $\gamma \delta$. Cold Spring Harbor Symp. Quant. Biol. 45, $135-140$.

Itakura, K., Hirose, T., Crea, R., Riggs, A. D., Heyneker, H. L., Bolivar, F., and Boyer, H. W. (1977). Expression in Escherichia coli of a chemically synthesized gene for the hormone somatostatin. Science 198, 1056-1063.

Lin-Chao, S., Chen, W-T., and Wong, T-T. (1992). High copy number of the pUC plasmid results from a Rom/ Rop-suppressible point mutation in RNA II. Mol. Microbiol. 6, 3385-3393.

Miller, H. I., and Friedman, D. I. (1980). An E. coli gene product required for lambda site-specific recombination. Cell 20, 711-719.

Miller, J. H. (1972). "Experiments in Molecular Genetics." Cold Spring Harbor Laboratory Press, Cold Spring Harbor, NY.

Müller-Hill, B. (1975). Lac repressor and lac operator. Prog. Biophys. Mol. Biol. 30, 227-252.

Müller-Hill, B. (1996). "The lac Operon: A Short History of a Genetic Paradigm.” de Gruyter, Berlin.

Ooki, K., Amuro, N., Shimizu, Y., and Okazaki, T. (1994). High level expression of rat gamma-D-crystallin in Escherichia coli. Biochimie 76, 398-403.

Posfai, G., Kiss, A., and Venetianer, P. (1986). Overproduction of the Bacillus sphaericus R modification methylase in Escherichia coli and its purification to homogeneity. Gene 50, 63-67.
Raleigh, E. A., Murray, N. E., Revel, H., Blumenthal, R. M., Westaway, D., Reith, A. D., Rigby, P. W., Elhai, J., and Hanahan, D. (1988). McrA and McrB restriction phenotypes and some $E$. coli strains and implications for gene cloning. Nucleic Acids Res. 16, 1563-1575.

Ranie, J., Kumar, V. P., and Balaram, H. (1993). Cloning of the triosephosphate isomerase gene of Plasmodium falciparum and expression in Escherichia coli. Mol. Biochem. Parasitol. 61, 159-169.

Scrutton, N. S., Berry, A., and Perham, R. N. (1987). Purification and characterization of glutathione reductase encoded by a cloned and over-expressed gene in Escherichia coli. Biochem. J. 245, 875-880.

Singer, M., Baker, T. A., Schnitzler, G., Deischel, S. M., Goel, M., Dove, W., Jaacks, K. J., Grossman, D., Erickson, J. W., and Gross, C. A. (1989). A collection of strains containing genetically linked altering antibiotic resistance elements for genetic mapping of Escherichia coli. Microbiol. Rev. 53, 1-24.

Studier, F. W. (1991). Use of bacteriophage-T7 lysozyme to improve an inducible T7 expression system. J. Mol. Biol. 219, 37-44.

Studier, F. W., and Moffatt, B. A. (1986). Use of bacteriophage T7 RNA polymerase to direct selective high-level expression of cloned genes. J. Mol. Biol. 189, 113-130.

Studier, F. W., Rosenberg, A. H., Dunn, J. J., and Dubendorff, J. W. (1990). Use of T7 RNA-polymerase to direct expression of cloned genes. In "Methods in Enzymology" (D. V. Goeddel, Ed.), Vol. 185, pp. 60-89. Academic Press, San Diego.

Vieira, J., and Messing, J. (1982). The pUC plasmids, an M13mp7-derived system for insertion mutagenesis and sequencing with synthetic universal primers. Gene 19, $259-268$.

Weisemann, J. A., and Weinstock, G. M. (1985). Direct selection of mutations reducing transcription or translation of the recA gene of Escherichia coli with a recAlacZ protein fusion. J. Bacteriol. 163, 748-755.

Yanisch-Perron, C., Vieira, J., and Messing, J. (1985). Improved M13 phage cloning vectors and host strains: Nucleotide sequences of the M13mp18 and pUC19 vectors. Gene 33, 103-119.

Zukowski, M. M., Gaffney, D. F., Speck, D., Kauffmann, M., Findeli, A., Wisecup, A., and Lecocq, J. P. (1983). Chromogenic identification of genetic regulatory signals in Bacillus subtilis based on expression of a cloned Pseudomonas gene. Proc. Natl. Acad. Sci. USA 80, 11011105.

Communicated by D. Chattoraj 